Teknik, 36 (2), 2015, 96-104

\title{
ARAHAN ZONASI DAN PENGEMBANGAN DI KAWASAN SITUS CAGAR BUDAYA PATIAYAM KABUPATEN KUDUS
}

\author{
Maulana Mohammad Atsnansyah ${ }^{*}$, Diah Intan Kusuma Dewi \\ Jurusan Perencanaan Wilayah dan Kota, Fakultas Teknik, Universitas Diponegoro, \\ Jl. Prof. Soedarto, SH, Kampus Undip Tembalang, Semarang, Indonesia 50275
}

\begin{abstract}
Abstrak
Kawasan Situs Cagar Budaya Patiayam di Desa Terban Kabupaten Kudus merupakan lokasi yang memerlukan tindakan pelestarian terhadap kebudayaan dan lingkungannya, karena di kawasan tersebut belum ada upaya keberlanjutan dalam menjaga dan melindungi kawasan situs cagar budaya serta belum adanya upaya pengembangan kebudayaan lokal pada kawasan tersebut. Berdasarkan permasalahan tersebut upaya yang dilakukan untuk meningkatkan fungsi dari kawasan adalah dengan membuat zonasi atau pembagian fungsi lahan yang jelas. Tujuan akhir yang diharapkan adalah untuk memberikan arahan zonasi pada setiap kawasan yang dijadikan sebagai kawasan konservasi dan kawasan wisata budaya. Tahapan awal dalam penelitian ini adalah dengan mengetahui potensi dan masalah yang terdapat pada kawasan tersebut melalui pengumpulan data yang bersifat kualitatif. Sedangkan untuk mengetahui arahan sesuai dengan potensi yang dimiliki serta menyelesaikan permasalahan yang ada di Kawasan Situs Cagar Budaya Patiayam menggunakan metode deskriptif kualitatif dan metode delphi. Hasil dari jawaban penelitian yang dilakukan terhadap Kawasan Situs Cagar Budaya Patiayam di Desa Terban Kabupaten Kudus ialah adanya zonasi yang jelas serta arahan pengembangan pada tiap kawasan. Pembagian zonasi pada kawasan Situs Cagar Budaya Patiayam dibagi menjadi 4 zona, yaitu zona inti, zona penyangga, zona pengembangan, dan zona penunjang.
\end{abstract}

Kata kunci : zonasi; situs cagar budaya patiayam; wisata budaya

\begin{abstract}
[Title: Zoning and Development Suggestions at Cultural Heritage Sites of Patiayam in Kudus Regency] Cultural Heritage Site of Patiayam in Terban Village Kudus Regency is a location that requires preservation towards its culture and environment, because in this area there is no sustained effort in maintaining and protecting the cultural heritage site, and lack of local cultural development efforts. Based on the problems, effort that should be done to improve the function of the area is by making a zoning or a clear division of land functions. The ultimate goal is to provide the zoning direction on each area that serve as a conservation area and the area of cultural tourism. The early stages in this research is to know the potential and problems in the area through the data collection with qualitative approach. As for knowing the direction corresponding with potential, as well as resolving existing problems in the area of cultural heritage Site of Patiayam, this research used qualitative-descriptive method and delphi method. The result of the research answer conducted towards the area of Cultural Heritage Site of Patiayam in Terban Village Kudus Regency is a clear zoning and direction of development in each area. Zoning division in the area of Cultural Heritage Sites of Patiayam is divided into four zones, namely the core zone, buffer zone, development zone and the supporting zone.
\end{abstract}

Keywords : zoning; cultural heritage site of patiayam; cultural tourism

\section{Pendahuluan}

Situs cagar budaya merupakan susunan binaan yang terbuat dari benda alam dan/atau benda buatan manusia untuk memenuhi kebutuhan ruang kegiatan

\footnotetext{
*) Penulis Korespondensi.
}

E-mail: maulana.mohammad15@pwk.undip.ac.id yang menyatu dengan alam, sarana, dan prasarana untuk menampung kebutuhan manusia (UU RI No.11 Tahun 2010). Salah satu situs cagar budaya di Kabupaten Kudus adalah Situs Pati Ayam yang terletak di Desa Terban Kabupaten Kudus.

Berdasarkan surat keputusan Kepala Balai Situs Patiayam yang terletak di Desa Terban Kabupaten Kudus merupakan salah satu situs cagar 


\section{Teknik, 36 (2), 2015, 97}

budaya yang ada di Jawa Tengah. Hal ini sesuai dengan surat keputusan Kepala Balai Pelestarian Peninggalan Purbakala (BP3) Provinsi Jawa Tengah Nomor 988/102.SP/BP3/P.IX/2005. Kawasan Situs Cagar Budaya Patiayam yang terletak di Desa Terban Kecamatan Jekulo Kabupaten Kudus mempunyai banyak potensi untuk pengembangan kawasan sebagai objek daya tarik wisata.

Sedangkan berdasarkan Rencana Induk Pengembangan Pariwisata Kabupaten Kudus, Kawasan Situs Cagar Budaya Patiayam sudah ditetapkan sebagai pengembangan kawasan wisata. Akan tetapi dalam upaya pengembangan di Kawasan Situs Cagar Budaya Patiayam masih menemui banyak permasalahan. Berbagai permasalahan tersebut salah satunya berdampak pada penurunan fungsi kawasan sebagai kawasan situs cagar budaya dan kawasan wisata budaya.

Dalam perkembangannya, upaya yang dilakukan untuk pengembangan wisata budaya dan pemeliharaan kawasan situs cagar budaya belum bisa maksimal. Adanya kawasan situs cagar budaya perlu dilakukan upaya konservasi sebagai langkah dalam mempertahankan keberlanjutannya (Sidharta dan Budihardjo, 1989). Selain itu, adanya kebudayaan lokal yang ada di kawasan ini perlu dikembangkan sebagai bentuk pelestarian kebudayaan lokal. Maka dari itu tujuan penelitian ini dilaksanakan adalah untuk merumuskan arahan pengembangan Kawasan Situs Cagar Budaya Patiayam Kabupaten Kudus.

Langkah yang dilakukan sebagai bentuk pelestarian kawasan situs cagar budaya dan kawasan wisata budaya ini adalah dengan memberikan arahan pengembangan yang sesuai dengan fungsinya. Adapun pentingnya arahan pengembangan pada kawasan situs cagar budaya bertujuan untuk mempertahankan, melindungi, memelihara, serta memanfaatkan tiap kawasan atau bangunan cagar budaya demi kepentingan pembangunan. Sedangkan arahan pada kawasan wisata budaya adalah untuk mengembangkan potensi kebudayaan lokal agar tetap eksis dan berkembang sehingga juga dapat mendatangkan kepentingan ekonomi bagi masyarakat lokal.

Upaya dalam memberikan arahan pengembangan pada kawasan situs cagar budaya adalah dengan memberikan arahan zonasi. Berdasarkan UU No 11 Tahun 2010 tentang cagar budaya, pembagian zonasi dalam kawasan cagar budaya dibagi menjadi peruntukkan 4 zona yaitu zona inti, zona penyangga, zona pengembangan, dan zona penunjang. Adanya zonasi ini juga berfungsi untuk mengidentifikasi dan menetapkan prioritas bagi pengembangan pada tiap kawasan, misalnya untuk pengembangan penelitian maupun pengembangan pariwisata. Melihat adanya potensi wisata budaya yang dimiliki daerah tersebut serta penelitian mengenai pengembangan kawasan cagar budaya di situs sejarah ini, diharapkan nantinya akan muncul arahan zonasi dan pengembangan Kawasan Situs Cagar Budaya Patiayam sebagai wisata budaya sehingga secara tidak langsung dapat memberi dampak positif bagi perkembangan pariwisata di daerah Kabupaten Kudus, masyarakat, dan lingkungan sekitarnya.

Menurut Budihardjo (1997), perkembangan kawasan cagar budaya menjadi kawasan wisata perlu adanya sebuah konsep yang cocok untuk mengembangkannya. Dalam hal ini upaya lain dalam pengembangan Situs Cagar Budaya Patiayam adalah dengan memberikan zonasi pada tiap kawasan. Sehingga nantinya akan diperoleh arahan pengembangan yang sesuai dengan zonasi kawasan di Situs Cagar Budaya Patiayam. Berkaitan dengan masalah tersebut, maka pertanyaan penelitian ini adalah "Bagaimana Arahan Zonasi dan Pengembangan Kawasan Situs Cagar Budaya Patiayam Kabupaten Kudus?

\section{Metode Penelitian}

Jenis metode yang digunakan dalam penelitian ini adalah kualitatif. Penelitian kualitatif ini digunakan karena jauh lebih subjektif daripada penelitian atau survei kuantitatif. Proses yang dilakukan dalam mengumpulkan informasi, terutama dalam mendapatkan informasi pada tiap individu, adalah dengan cara menggunakan wawancara secara mendalam dan grup fokus (Sugiyono, 2009).

Alur dalam mendapatkan informasi penelitian diawali dengan mengidentifikasi sejarah dan perkembangan pada kawasan patiayam. Setelah mendapatkan informasi tersebut, selanjutnya dibagi untuk menjadi potensi dan masalah pengembangan kawasan. Potensi dan masalah tersebut ditanyakan kepada beberapa warga masyarakat yang dianggap tokoh dalam kawasan tersebut. Setelah mendapat informasi potensi dan masalah, kemudian didapatkan beberapa aspek yang dapat mempengaruhi pengembangan dari Kawasan Patiayam. Hasil aspek tersebut yang nantinya akan dibawa ke responden delphi untuk mendapatkan arahan zonasi dan pengembangannya.

Identifikasi sejarah dan perkembangan yang dilakukan di Kawasan Situs Cagar Budaya Patiayam adalah dengan melakukan analisis deskriptif kualitatif dengan metode historis. Dalam mengidentifikasi sejarah dan perkembangan kawasan situs cagar budaya Patiayam di Kabupaten Kudus kegiatan yang dilakukan adalah melakukan wawancara dan observasi lapangan. Observasi ini dilakukan dengan tujuan untuk menemukan fakta yang ada di lokasi wilayah penelitian. Beberapa objek yang akan di observasi berdasarkan hasil sintesa kajian pustaka. Hasil temuan fakta di lapangan dikomparasikan dengan informasi yang didapatkan dari para ahli.

Identifikasi potensi dan masalah yang berpengaruh dalam pengembangan kawasan situs cagar budaya Patiayam Kabupaten Kudus dilakukan dengan metode analisis deskriptif. Kegiatan yang dilakukan untuk mendapatkan potensi dan masalah adalah melakukan kegiatan wawancara. Variabel yang akan ditanyakan berdasarkan kajian literatur yang sudah dianalisis. Variabel tersebut diantaranya adalah 


\section{Teknik, 36 (2), 2015, 98}

mengenai perkembangan kondisi peninggalan situs cagar budaya, objek/atraksi dan daya tarik wisata, transportasi, infrastruktur, akomodasi (tempat menginap), usaha makanan dan minuman, jasa pendukung lainnya, informasi, promosi, kebudayaan lokal, dan aktivitas perilaku masyarat di Kawasan Situs Cagar Budaya

Jumlah narasumber yang ditetapkan sebagai target informasi adalah sebanyak 20 narasumber. Narasumber yang menjadi target untuk mendapatkan informasi adalah perangkat Desa Terban yang dianggap mengerti sejarah dan perkembangan Desa Terban serta kegiatan pengembangan terhadap Kawasan Situs Cagar Budaya Patiayam. Hasil dari pendapat berbagai perangkat kemudian dilakukan analisis deskriptif guna mendapatkan potensi dan masalah yang berpengaruh dalam pengembangan kawasan.

Metode analisa terakhir yang digunakan dalam menentukan aspek-aspek yang berpengaruh dalam pengembangan kawasan, pembagian zonasi kawasan, serta perumusan arahan pengembangan Kawasan Situs Cagar Budaya Patiayam sebagai kawasan wisata budaya menggunakan metode analisis delphi. Penggunaan teknik analisis delphi bertujuan untuk mencari kesepakatan pendapat dari suatu kasus diantara 20 narasumber tersebut.

Dalam menentukan zonasi dan arahan pelestarian di Kawasan Situs Cagar Budaya Patiayam, langkah yang dilakukan adalah seperti halnya menentukan aspek pengembangan. Hasil konsensus aspek pengembangan dari analisis delphi putaran pertama kemudian dieksplorasi untuk menentukan zonasi dan arahan pengembangan per zona di Kawasan Situs Cagar Budaya Patiayam. Para ahli diminta mengkaji hasil dari delphi putaran pertama, kemudian diberikan kewenangan untuk memberikan pendapat dalam membagi aspek pengembangan tersebut ke dalam 4 zona, yaitu zona inti, zona penyangga, zona pengembangan, dan zona penunjang.

\section{Hasil Pembahasan}

3.1 Mengidentifikasi sejarah dan perkembangan Kawasan Situs Cagar Budaya Patiayam Desa Terban Kabupaten Kudus yang merupakan situs cagar budaya yang akan dikembangkan sebagai Wisata Budaya

Berbagai temuan yang didapatkan hasil identifikasi sejarah dan perkembangan kawasan dari para narasumber diantaranya adalah sejarah Situs Patiayam, merupakan kawasan purba yang tersisa di Jawa bagian utara. Kawasan ini pada abad 16 merupakan selat muria yang konon masih bisa dilayari. Akan tetapi, menurut Supani dkk. (2009), dalam bukunya Benda Cagar Budaya Peninggalan Sejarah dan Purbakala Kabupaten Kudus pada abad ke 18, Kawasan Patiayam menyambung dengan Pulau Jawa.

Rangkaian penelitian telah dilakukan di situs ini, mulai dari tahun 1931 saat peneliti asal Belanda Van Es menemukan sembilan jenis fosil hewan vertebrata. Situs Patiayam mempunyai ciri khas dengan banyaknya penemuan Gajah Purba, terutama penemuan spesies Stegodon trigonochepalus dengan gading purba yang berukuran 2,7 dan 3,7 meter pada tahun 1982 (Supani, dkk. 2009). Berdasarkan dengan banyaknya penemuan di Kawasan Patiayam, Pada tanggal 2 Oktober 2005, Situs Patiayam ditetapkan sebagai kawasan Benda Cagar Budaya (BCB) oleh Kepala Balai Pelestarian dan Peninggalan Purbakala (BP3) Jawa Tengah, Pada tanggal 2 Oktober 2005. Pada Tanggal 5 Desember 2005, rumah warga bernama Jasmani Mendeng digunakan untuk rumah fosil. Hal ini dikarenakan dengan mulai banyaknya penemuan fosil, sehingga diperlukan tempat untuk menyimpan dan menjaga fosil yang telah ditemukan (Soekojo, 2008).

Sepanjang tahun 2006-2008 terus dilakukan penelitian berupa ekskavasi, survey, dan pemetaan di Kawasan Patiayam. Pada Rencana Induk Pengembangan Pariwisata Kabupaten Kudus Tahun 2010, Kawasan Patiayam ekstensifikasi atau pengembangan produk wisata baru sebagai produk wisata budaya. Upaya pengembangan kawasan ini sebagai kawasan wisata budaya dan cagar budaya diantaranya adalah dengan membangun museum fosil patiayam. Tahun 2014, Museum Fosil Patiayam dibangun sebagai ganti rumah fosil dari rumah penduduk.

\subsection{Analisis potensi dan masalah pengembangan Kawasan Situs Cagar Budaya Patiayam Kabupaten Kudus \\ Pada analisis ini, keluaran yang dihasilkan} adalah hasil jawaban dari beberapa narasumber yang memberikan pendapat mengenai potensi dan masalah yang berkembang di Kawasan Situs Cagar Budaya Patiayam. Potensi dan masalah yang didapatkan nantinya menjadi bahan yang digunakan dalam analisis selanjutnya.

Para narasumber memberikan kesimpulan pendapat mengenai potensi di Kawasan Situs Cagar Budaya Patiayam, diantaranya adalah kondisi dan perkembangan situs cagar budaya yang unik dan tidak ditemukan ditempat lain. Berdasarkan penelitian yang telah dilakukan, di Kawasan Situs Cagar Budaya Patiayam memang banyak penemuan fosil yang masih dalam keadaan utuh. Fosil yang ditemukan kebanyakan adalah fosil gajah purba. Potensi ini juga didukung oleh pendapat ahli berikut:

“...Ya perlu, perkembangan temuan fosil sangat banyak dan tidak ditemukan ditempat lain. Jadi perlu adanya upaya pengembangan dengan adanya rumah fosil yang layak." (Narasumber 1)

Selain itu adanya objek atau daya tarik wisata lain seperti air terjun, sendang dan festival budaya. Adanya jasa pendukung lainnya, promosi, informasi, kebudayaan lokal, aktivitas dan peran serta masyarakat juga merupakan potensi yang berkembang di kawasan ini. Berdasarkan hasil pengamatan, potensi tersebut sebagian besar merupakan kegiatan yang sudah dilaksanakan. 


\section{Teknik, 36 (2), 2015, 99}

Persebaran titik potensi yang ada di Kawasan Situs Cagar Budaya Patiayam dapat dilihat di Gambar 1. Beberapa potensi yang ada di Kawasan Situs Cagar Budaya Patiayam sebagian besar belum dikembangkan dan dimanfaatkan sebagai daya tarik dan nilai jual kawasan.

Adapun menurut para narasumber, masalah yang berpengaruh dalam pengembangan wisata budaya di Kawasan Situs Cagar Budaya Patiayam diantaranya yaitu tindakan pelestarian, transportasi dan infrastruktur, akomodasi, tempat usaha, alih fungsi lahan, dan peraturan tata guna lahan (Gambar 2). Kendala pengembangan tersebut merupakan masalah yang masih terdapat di kondisi eksisting. Peran masyarakat yang antusias terhadap penemuan fosil-fosil di Kawasan Situs Cagar Budaya Patiayam, tidak diimbangi usaha pemerintah dalam melestarikan dan menjaga kawasan tersebut. Beberapa fosil yang ditemukan sebagian besar dalam kondisi yang memprihatinkan, adanya rumah fosil yang ada tidak cukup untuk menampung fosil yang ditemukan. Selain itu, kurangnya tenaga ahli dalam merawat kondisi fosil mengakibatkan banyak fosil yang lapuk serta terjadinya sabotase. Banyaknya fosil yang belum ditemukan juga tidak dilakukan upaya penggalian atau penelitian lebih lanjut. Hal ini sangat beresiko untuk terjadinya sabotase di Kawasan Situs Cagar Budaya Patiayam. Kurang adanya tindakan pelestarian tersebut, didukung dengan salah satu pendapat narasumber berikut:

“...Pemerintah hanya membantu dalam kegiatan penelitian, setelah kegiatan penelitian tidak adanya kegiatan pelestarian lingkungan." (Narasumber 5) "...Bantuan pemerintah sejauh ini hanya mengadakan penelitian, belum adanya upaya pelestarian kawasan untuk dijadikan kawasan komersial yang layak." (Narasumber 1).

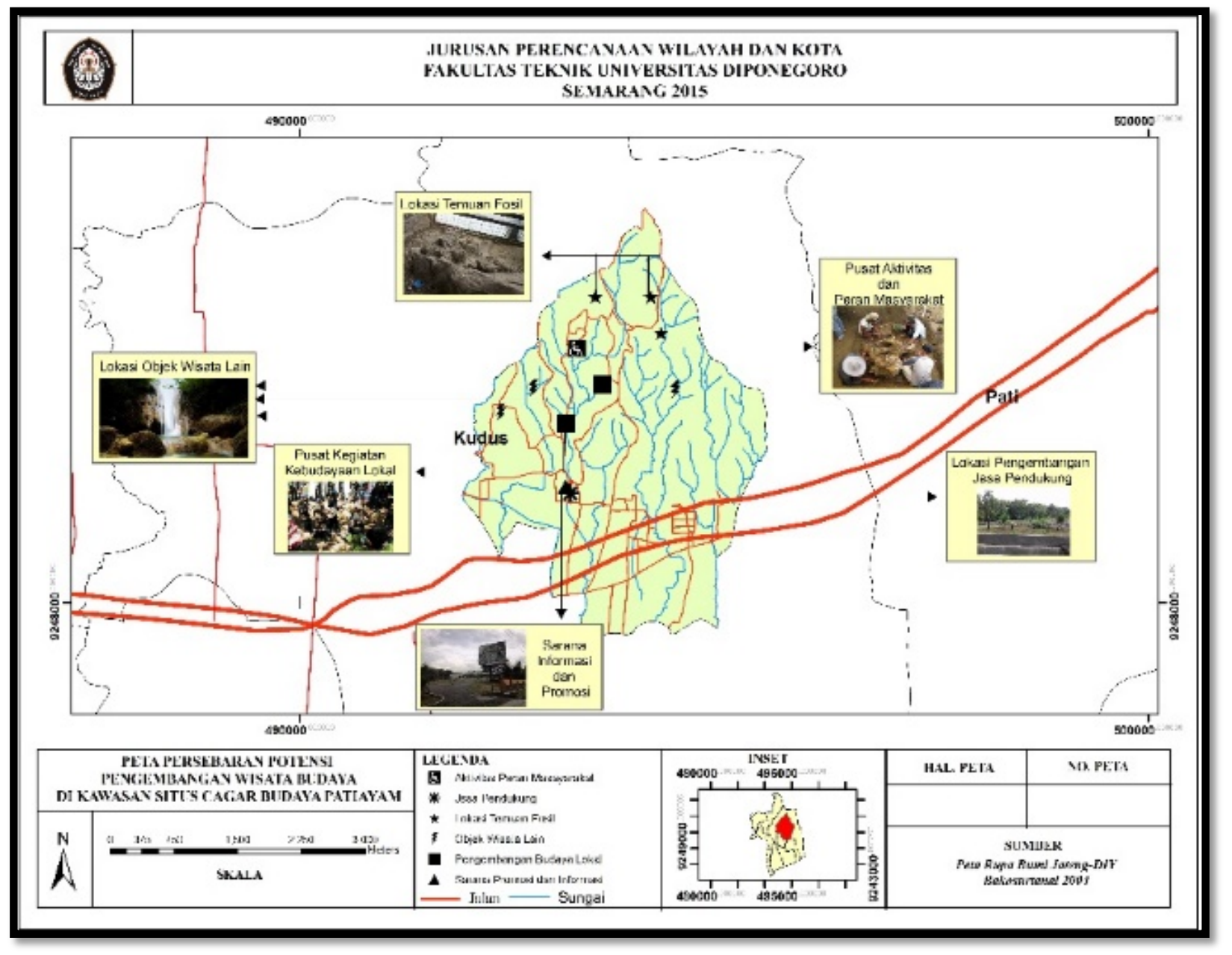

Gambar 1. Peta Persebaran Potensi di Kawasan Situs Cagar Budaya Patiayam (Peta Rupa Bumi Jawa Tengah Bakosurtanal, 2010) 


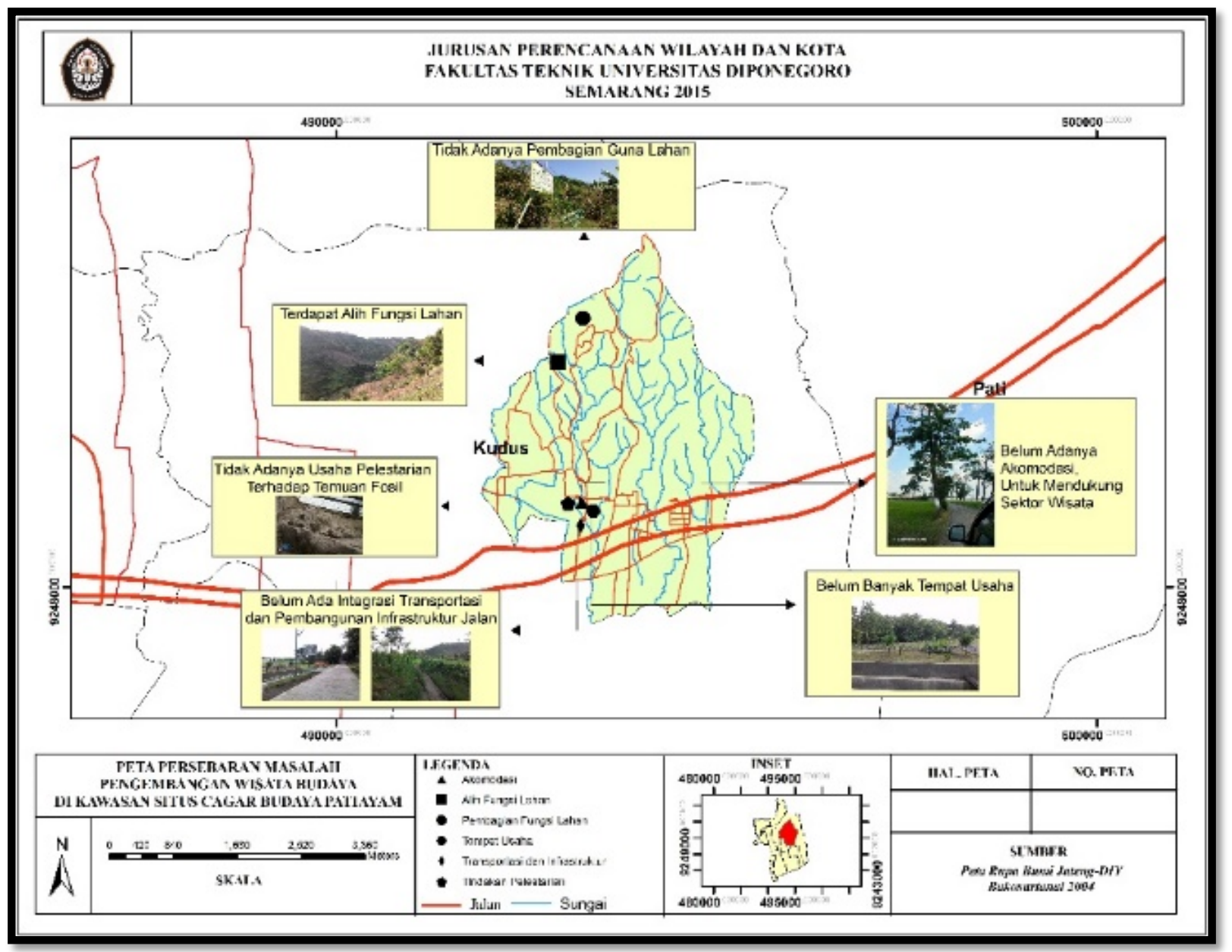

Gambar 2. Peta Persebaran Masalah di Kawasan Situs Cagar Budaya Patiayam (Peta Rupa Bumi Jawa Tengah Bakosurtanal, 2010)

\subsection{Menganalisis aspek yang berpengaruh dalam pengembangan Kawasan Situs Pati Ayam Desa Terban melalui Analisis Delphi}

Proses dalam menganalisis aspek yang berpengaruh menggunakan teknik analisis delphi. Adapun langkah untuk menentukan faktor yang berpengaruh diantaranya dengan menentukan stakeholder kunci. Stakeholder kunci tersebut adalah Kepala Bidang Pariwisata Disbudpar, Kepala Bidang Kebudayaan Disbudpar, Kasi Cagar Budaya, Kasi Pengembangan Wisata dan Juru Pelihara Patiayam. Potensi dan kendala hasil dari analisis deskriptif digunakan sebagai kunci untuk menentukan faktor pengembangan. Langkah selanjutnya yaitu mengumpulkan dan memverifikasi hasil pendapat stakeholders dalam hal menentukan faktor pengembangan dan dilanjutkan dengan mengintepretasi kecenderungan pendapat para stakeholder.

Dari tahap tersebut maka akan diperoleh kesepakatan pendapat yang merupakan hasil akhir diantara kelompok stakeholders yang homogen. Hasil dari analisis delphi tersebut, maka beberapa aspek yang berpengaruh dalam pengembangan kawasan adalah Potensi Kawasan Patiayam yang salah satu temuan fosilnya yang unik dan tidak ditemukan ditempat lain. Sejarah dari situs yang ditemukan merupakan saksi dari terbentuknya Kawasan Patiayam, sedangkan fosil gajah purba yang ditemukan di kawasan ini merupakan ikon dari Kawasan Patiayam. Oleh karena itu, diperlukan pengembangan Kawasan Patiayam agar tetap terjaga.

Aspek lain yang berpengaruh yaitu adanya objek wisata alam: air terjun, sendang, goa jepang dan adanya budaya lokal baik dari kesenian teater, musik, rupa, dan tari. Banyaknya objek yang menjadi daya tarik dapat dijadikan salah potensi dalam meningkatkan nilai jual kawasan ini. Selain itu, juga terdapat jasa pendukung wisata sudah tersedia dengan adanya juru pelihara museum dan pemandu wisata. Akan tetapi pelayanan fasilitas pendukung berupa tempat pertunjukkan kesenian dan perbelanjaan untuk memenuhi kebutuhan wisatawan sangat diperlukan sebagai salah satu pengembangan wisata di kawasan ini.

Promosi dan Informasi pariwisata merupakan satu bagian dalam mengenalkan kawasan ini. Langkah yang dilakukan melalui papan informasi dan media sosial, cetak, dan elektronik yang dilakukan untuk menarik wisatawan lebih banyak datang. Selain itu juga dapat dilakukan promosi dalam pameran tingkat provinsi dan nasional untuk menarik wisatawan lebih banyak dating. Pengembangan budaya lokal dengan adanya festival patiayam perlu ditingkatkan. Hal ini 


\section{Teknik, 36 (2), 2015, 101}

berdasarkan dengan banyaknya budaya lokal yang berkembang di Kawasan Patiayam.

Adanya dukungan dan partisipasi dari masyarakat sekitar, Lembaga Swadaya Masyarakat, kelompok kelompok masyarakat yang berkaitan dengan pelestarian Situs Patiayam, seperti PPSP, FPSP, dan Pokdarwis perlu dimanfaatkan untuk pelestarian dan pengembangan Kawasan Patiayam. Sedangkan Sarana transportasi dan infrastruktur untuk menjangkau lokasi atau objek yang ada di Kawasan Patiayam perlu dibenahi sebagai bentuk dukungan terhadap pengembangan kawasan. Tindakan pelestarian sangat diperlukan untuk menjaga lingkungan di Kawasan Patiayam. Salah satu tindakan yang dapat dilakukan dalam melestarikan fosil adalah membangun lokasi baru sebagai tempat untuk menyimpan fosil yang ditemukan. Selain itu, tindakan dapat dilakukan dengan cara konservasi pada lokasi penemuan situs purbakala.

Penyediaaan sarana akomodasi untuk memenuhi kenyamanan wisatawan sangat diperlukan untuk masa mendatang dan harus dimasukkan dalam rencana pengembangan. Ketersediaan lahan yang sudah disediakan pemerintah, perlu diupaya dengan dibangun tempat usaha untuk memfasilitasi wisatawan, dan menaikkan pendapatan warga local. Tindakan pengelolaan lingkungan cagar budaya harus dilakukan oleh semua pihak yang terkait dalam tindakan pelestarian dan pengembangan Kawasan Patiayam. Oleh karena itu, perlu adanya tindakan dalam pencegahan alih fungsi lahan. Adanya peraturan zonasi yang jelas untuk melindungi kawasan konservasi agar tetap terjaga. Aturan zonasi ini juga berfungsi untuk memberikan arahan pengembangan dan pelestarian kawasan.

Proses dalam mendapatkan aspek-aspek tersebut dilakukan dengan Analisis Delphi. Langkah yang dilakukan berawal dari hasil kuesioner potensi dan masalah pengembangan di Kawasan Cagar Budaya Patiayam. Berdasarkan potensi dan masalah yang ada di lapangan, para stakeholder memberikan pendapat jika semua potensi dan masalah tersebut merupakan salah satu hal yang diperlukan dalam pengembangan wisata budaya. Para stakeholder memberikan pendapatnya masing-masing terhadap aspek yang diperlukan dalam mengembangkan wisata budaya di Kawasan Situs Cagar Budaya. Secara keseluruhan aspek yang didapatkan diantaranya dari memaksimalkan potensi yang ada serta memperbaiki kendala yang selama ini masih menjadi masalah.

\subsection{Perumusan arahan pengembangan Kawasan Situs Cagar Budaya Patiayam Desa Terban}

Perumusan arahan pengembangan di Kawasan Situs Cagar Budaya Patiayam bertujuan untuk menentukan zonasi sebagai arahan dalam pengembangan. Proses dalam merumuskan arahan pengembangan adalah dengan melakukan langkah seperti halnya menentukan aspek yang berpengaruh. Hasil dari analisis delphi putaran pertama yaitu aspek pengembangan kemudian dieksplorasi untuk menentukan zonasi dan arahan pengembangan di Kawasan Situs Cagar Budaya Patiayam. Penentuan zonasi dan arahan pengembangan dilakukan dengan menggunakan metode Delphi.

Tahapan merumuskan arahan pengembangan Kawasan Situs Cagar Budaya Patiayam, terlebih dahulu menetapkan zonasi pada kawasan tersebut. Penentuan zonasi tersebut dilakukan dengan analisis delphi dengan meminta pendapat dari beberapa ahli. Hasil dari analisis delphi kemudian dikomparasikan dengan UU Cagar Budaya No. 11 Tahun 2010 untuk menghasilkan arahan zonasi dengan pembagian sebagai zona inti, zona penyangga, zona pengembangan, dan zona penunjang.

Berdasarkan hasil dari analisis Delphi, maka didapatkan zona dan arahan pengembangan diantaranya adalah:

\section{Zona Inti}

Zona inti merupakan kawasan utama penemuan fosil yang menjadi ikon dan daya tarik Kawasan Situs Cagar Budaya Patiayam. Pada kawasan inti terdapat radius pemeliharaan zona inti adalah $500 \mathrm{~m}$ dari lokasi penemuan. Jarak $500 \mathrm{~m}$ didapatkan dari hasil konsensus atau kesepakatan dari analisis delphi. Dalam menjaga zona inti maka dilakukan tindakan pelestarian secara dinamis dan akif, yaitu konservasi pada kawasan inti. Selain itu juga harus ada sterilisasi zona inti dari kegiatan manusia, yaitu dengan memberikan barrier antara lokasi inti dengan aktivitas manusia.

Kegiatan yang dilakukan di zona ini adalah kegiatan yang berhubungan dengan penelitian dan kegiatan pelestarian. Penelitian berkelanjutan yang dilakukan di zona inti bertujuan untuk menemukan fosil-fosil baru yang masih terkubur. Selain itu, perlu adanya peraturan yang jelas seperti masterplan dan RTBL agar pengembangan dan penggunaan lahan semakin jelas. Pengalokasian anggaran dana juga diperlukan untuk pengembangan Kawasan Patiayam.

\section{Zona Penyangga}

Zona penyangga merupakan area yang melindungi zona inti yang berkaitan dengan tindakan pelestarian dan aktivitas kegiatan masyarakat. Lokasi zona penyangga terletak pada radius $500 \mathrm{~m}$ dari zona inti terluar. Jarak $500 \mathrm{~m}$ didapatkan dari hasil konsensus atau kesepakatan dari analisis delphi. Kegiatan yang berada di lokasi zona penyangga ada kegiatan yang dilakukan dengan komunitas masyakat untuk melestarikan situs cagar budaya yang berupa peningkatan pemeliharaan melalui perawatan di sekitar lokasi titik temu, agar kondisi lahan tidak terjadi alih fungsi oleh kegiatan manusia.

Mengadakan kerjasama antara komunitas, penyelamat Kawasan Patiayam, kelompok sadar wisata, pemerintah dan masyarakat di Kawasan Patiayam. Tujuan kerjasama ini adalah untuk melindungi situs cagar budaya dengan membangun museum atau rumah fosil yang layak untuk menampung seluruh fosil yang ditemukan pada 


\section{Teknik, 36 (2), 2015, 102}

kawasan penyangga. Para ahli juga menyarankan untuk membangun museum atau rumah fosil yang lebih layak di zona penyangga. Tujuan dari pembangunan museum di zona penyangga berfungsi untuk peningkatan pemeliharaan melalui perawatan fosil agar tidak mudah rusak. Selain itu juga perlu adanya juru pelihara di area zona penyangga maupun di museum. Tujuan adanya juru pelihara ini diperlukan untuk membantu pengelolaan lingkungan pada kawasan penyangga dan museum. Selain itu, juru pelihara tersebut juga perlu dibekali pelatihan untuk menambah informasi dan pengetahuan lebih mengenai pemeliharaan dan pelestarian situs cagar budaya, agar kondisi di museum dan zona penyangga memang benar terawat.

\section{Zona Pengembangan}

Kawasan ini merupakan kawasan yang secara langsung mendukung kegiatan wisata cagar budaya yang merupakan pusat dari fasilitas pelayanan kegiatan pariwisata yang dibutuhkan oleh masyarakat dan juga wisatawan seperti perdagangan jasa. Zona pengembangan berada kurang lebih sekitar 500m $1 \mathrm{~km}$ dari zona penyangga. Jarak 500m - $1 \mathrm{~km}$ didapatkan dari hasil konsensus atau kesepakatan dari analisis delphi. Pada zona pengembangan kegiatan yang dilakukan adalah melakukan tindakan pemeliharaan terhadap objek wisata alam dan wisata budaya, agar tetap terjaga kelestariannya. Berdasarkan hasil pendapat para ahli, kebanyakan menyarankan jika dalam menjaga kebudayaan lokal, maka harus lebih banyak diadakan pagelaran seni. Hal ini bertujuan untuk mengajak masyarakat lokal untuk lebih menjaga dan mewarisi tradisi lokal.

Pada zona pengembangan lebih diarahkan sebagai zona pengembangan wisata budaya. Salah satu cara yang dapat dilakukan adalah melaksanakan festival patiayam yang berisi kesenian lokal berupa wayang dongeng, tari kretek, rebana, serta dolanan anak. Untuk menambah daya tarik festival patiyam dengan mengangkat kebudayaan lokal, maka dapat dilakukan dengan peningkatan ragam seni budaya di festival patiayam berupa kerjasama dengan komunitas pecinta budaya di dalam menyelenggarakan festival patiayam.

Hal lain yang dilakukan untuk mendukung zona pengembangan di Kawasan Patiayam adalah dengan memperbaiki akses jalan menuju kawasan yang dijadikan objek wisata, meningkatkan kualitas transportasi untuk tracking menuju kawasan cagar budaya dan membuat sistem parkir terpusat.

\section{Zona Penunjang}

Zona penunjang adalah area yang diperuntukkan bagi sarana dan prasarana penunjang serta untuk kegiatan komersial dan rekreasi umum. Zona penunjang pengembangan kawasan wisata budaya terletak pada radius $500 \mathrm{~m}$ dari zona pengembangan. Jarak 500m didapatkan dari hasil konsensus atau kesepakatan dari analisis delphi. Pada zona ini juga harus tersedia sarana akomodasi dan sarana pendukung wisata serta berbagai sarana penunjang lainnya. Selain itu juga harus tersedia sarana pariwisata berupa gedung pertunjukkan budaya lokal, museum, galeri seni dari masyarakat lokal serta penyediaan lahan untuk perbelanjaan sebagai pendukung wisata budaya

Zona penunjang merupakan lokasi yang tepat sebagai sarana meningkatkan promosi (informasi) cagar budaya secara langsung (fisik) dan meningkatkan promosi (informasi) cagar budaya secara tidak langsung (non fisik). Upaya dalam mendukung pengembangan kawasan wisata budaya di Kawasan Situs Cagar Budaya Patiayam juga perlu untuk menyediakan signage sebagai penanda untuk sarana informasi di beberapa objek wisata, membangun penginapan berupa homestay yang berijin resmi untuk mendekatkan wisatawan kepada kebudayaan lokal.

\section{Kesimpulan dan Rekomendasi 4.1 Kesimpulan}

Kawasan Situs Cagar Budaya Patiayam merupakan salah satu situs cagar budaya yang tersebar di Indonesia. Patiayam merupakan salah satu situs yang terletak di Desa Terban, Kabupaten Kudus. Kawasan Situs Cagar Budaya Patiayam mulai ditetapkan sebagai situs cagar budaya sejak tahun 2005. Sedangkan dalam perkembangannya, pada tahun 2010 berdasarkan Rencana Induk Pengembangan Pariwisata Kabupaten Kudus di Kawasan Situs Cagar Budaya Patiayam ditetapkan sebagai kawasan wisata.

Arahan zonasi di Kawasan Situs Cagar Budaya Patiayam bertujuan untuk menyelamatkan seluruh kawasan cagar budaya tersebut agar terjaga, terawasi, dan terproteksi dari berbagai gangguan dan ancaman dari luar. Zonasi tersebut juga berfungsi sebagai pengendali ruang. Hal ini bertujuan untuk memperbaiki suatu kegiatan yang telah berlangsung lama namun keberadaanya tidak sesuai dengan rencana tata ruang yang ada. Selain itu, zonasi mempunyai fungsi untuk mencegah terjadinya pembangunan yang tidak sesuai dengan acuan yang telah disusun. Sehingga nantinya nilai fungsi Kawasan Situs Cagar Budaya Patiayam tidak mengalami penurunan dan dapat meningkatkan nilai kawasan sebagai kawasan situs cagar budaya dan wisata budaya. Adapun arahan yang dihasilkan dari penelitian ini menjelaskan bahwa Kawasan Situs Cagar Budaya Patiayam dibagi menjadi 4 zonasi, yang terbagi menjadi zona inti, zona penyangga, zona pengembangan, dan zona penunjang. 


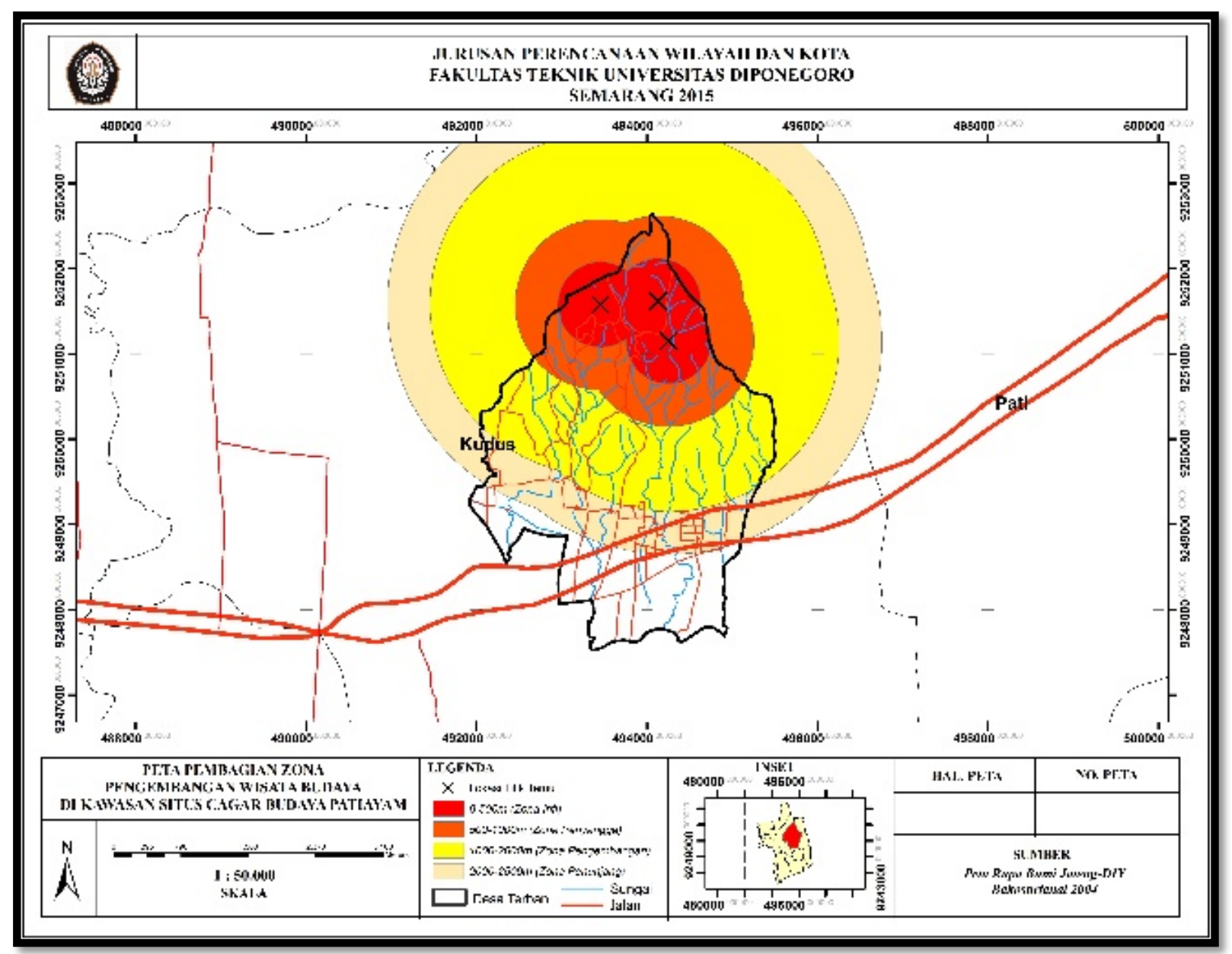

Gambar 3. Peta Pembagian Zonasi Kawasan Situs Cagar Budaya Patiayam (Peta Rupa Bumi Jawa Tengah Bakosurtanal, 2010)

Jarak pengembangan zona inti adalah $500 \mathrm{~m}$ dari lokasi penemuan. Penentuan jarak zona inti ini didasarkan pada penemuan fosil yang masih banyak pada radius $500 \mathrm{~m}$. Pada zona ini, kegiatan yang dilakukan di zona ini adalah kegiatan yang berhubungan dengan penelitian yaitu berupa kegiatan survei dan ekskavasi. Kegiatan penelitian berkelanjutan yang dilakukan di zona inti bertujuan untuk menemukan fosil-fosil baru yang masih terkubur, termasuk kawasan perhutani. Oleh sebab itu, aktivitas produksi yang dilakukan di lahan perhutani harus dibatasi.

Lokasi zona penyangga terletak pada radius $500 \mathrm{~m}$ dari zona inti terluar. Penentuan zona penyangga didasarkan pada temuan serpihan yang masih ditemukan di luar zona inti. Oleh sebab itu, pada zona penyangga kegiatan difokuskan hanya untuk kegiatan dalam mendukung penelitian di zona inti. Kegiatan yang dapat dilakukan pada zona penyangga adalah memberi barrier pada zona penyangga untuk membatasi zona inti dengan zona pengembangan serta membangun museum atau rumah fosil yang layak untuk menampung seluruh fosil yang ditemukan.

Zona pengembangan terletak kurang lebih sekitar $500 \mathrm{~m}-1 \mathrm{~km}$ dari zona penyangga. Zona pengembangan terletak sekitar $1,5 \mathrm{~km}$ dari zona inti.
Hal ini dikarenakan kegiatan zona pengembangan difokuskan untuk kegiatan wisata budaya. Pada zona pengembangan ini aktivitas wisata yang dapat dilakukan adalah melaksanakan festival patiayam yang berisi pagelaran kesenian lokal.

Zona penunjang pengembangan kawasan wisata budaya terletak pada radius $500 \mathrm{~m}$ dari zona pengembangan.Pada zona ini juga harus tersedia sarana pariwisata berupa sarana akomodasi dan tempat usaha, gedung pertunjukkan budaya lokal, museum, galeri seni dari masyarakat lokal serta penyediaan lahan untuk perbelanjaan sebagai pendukung wisata budaya. Selain itu, pembangunanan infrastruktur jalan dan sarana transportasi harus dimulai dari zona penunjang hingga zona inti. Hal ini untuk memudahkan untuk menjangkau setiap objek yang ada pada setiap zona.

\subsection{Rekomendasi}

Perkembangan yang terjadi di Kawasan Situs Cagar Budaya Patiayam mengakibatkan perkembangan fungsi kawasan yang mendorong adanya tindak lanjut dalam perencanaan wilayah dan kota agar perkembangan Kawasan Situs Cagar Budaya Patiayam sesuai dengan karakteristik aktivitas yang ada di dalamnya. Untuk itu, diperlukan adanya rekomendasi bagi pembuat dan penentu kebijakan 


\section{Teknik, 36 (2), 2015, 104}

berdasarkan hasil temuan studi dan kesimpulan agar dapat dijadikan sebagai salah satu dasar pertimbangan dalam menyusun kebijakan dalam pengembangan Kawasan Situs Cagar Budaya Patiayam sebagai kawasan wisata. Adapun rekomendasi tersebut adalah sebagai berikut:

a. Meningkatkan sarana pendukung wisata seperti sarana akomodasi dan tempat usaha, gedung pertunjukkan budaya lokal, museum, galeri seni dari masyarakat lokal serta penyediaan lahan untuk perbelanjaan sebagai pendukung wisata budaya, untuk mendukung peningkatan wisata berkelanjutan di Kawasan Situs Cagar Budaya Patiayam.

b. Meningkatkan kecintaan masyarakat untuk menjaga dan melestarikan budaya lokal, dengan sering mengadakan pagelaran seni lokal yang didukung oleh pemerintah.

c. Memberikan dukungan berupa bantuan kepada pemerintah Desa Terban berupa penyediaan lahan, untuk membangun museum atau rumah fosil.

d. Memberikan ganti rugi lahan dan memberikan arahan kepada perhutani untuk menyelesaikan masalah penemuan fosil yang masih ada dilahan perhutani dan masyarakat.

e. Peningkatan kerjasama antara masyarakat dan pemerintah dalam usaha menyelamatkan fosil di Kawasan Situs Cagar Budaya Patiayam dengan mengadakan penelitian berupa survei dan ekskavasi di zona inti.

f. Pengembangan wisata budaya dengan membangun integrasi antara wisata budaya, alam dan sejarah dengan membangun jaringan transportasi yang menjangkau setiap kawasan.

g. Membuat peraturan yang jelas mengenai zonasi dan penggunaan lahan di Kawasan Situs Cagar Budaya Patiayam sepeti RTBL dan masterplan.

\section{Daftar Pustaka}

Abrams, C. (1964). Housing in the Modern World. Man's Struggle for Shelter in an Urbanizing World. Africa Today, 11(8). 12-14: Indiana University Press.

Budihardjo, E. (1997). Lingkungan Binaan dan Tata Ruang Kota. Yogyakarta: Gajah Mada University Press.

Dokumen SHP. Badan Koordinasi Survei dan Pemetaan Nasional Tahun 2010.

Rencana Induk Pengembangan Pariwisata Kabupaten Kudus.

Supani, S.D. dkk. (2009). Benda Cagar Budaya Peninggalan Sejarah dan Purbakala Kabupaten Kudus. Kudus: Disbudpar Kabupaten Kudus

Sidharta dan Budihardjo, E. (1989). Konservasi Lingkungan dan Bangunan Kuno Bersejarah di Surakarta. Yogyakarta: Gajah Mada University Press.

Sugiyono, S. (2009). Metode Penelitian Kualitatif. Bandung: CV Alfabeta.

Surat keputusan Kepala Balai Pelestarian Peninggalan Purbakala (BP3) Provinsi Jawa Tengah nomor 988/102.SP/BP3/P.IX/2005

Soekojo dkk. (2008). Peninggalan Sejarah dan Purbakala Kabupaten Kudus. Kudus: Disbudpar Kab. Kudus.

UU RI No.11 Tahun 2010 tentang Cagar Budaya. 